Research Article

\title{
Preferential induction of MLL (Mixed Lineage Leukemia) rearrangements in human lymphocyte cultures treated with etoposide
}

\author{
María Sol Brassesco ${ }^{1,2}$, Ana Paula Montaldi ${ }^{1}$ and Elza Tiemi Sakamoto-Hojo ${ }^{1,3}$ \\ ${ }^{1}$ Departamento de Genética, Faculdade de Medicina de Ribeirão Preto, \\ Universidade de São Paulo, Ribeirão Preto, SP, Brazil. \\ ${ }^{2}$ Departamento de Puericultura e Pediatria, Faculdade de Medicina de Ribeirão Preto, \\ Universidade de São Paulo, Ribeirão Preto, SP, Brazil. \\ ${ }^{3}$ Departamento de Biologia, Faculdade de Filosofia Ciências e Letras de Ribeirão Preto, \\ Universidade de São Paulo, Ribeirão Preto, SP, Brazil.
}

\begin{abstract}
Topoisomerase II inhibitors are effective chemotherapeutic agents in the treatment of cancer, in spite of being associated with the development of secondary leukemia. Our purpose was to determine the effects of etoposide on different genomic regions, aiming at discovering whether there are preferential sites which can be targeted by this drug in peripheral lymphocytes from healthy individuals. The in vitro treatment with low doses of etoposide $(0.25,0.5$, and $1 \mu \mathrm{g} / \mathrm{mL}$, in 1 hour-pulse or continuous-48 $\mathrm{h}$ treatment) induced a significant increase in chromosomal aberrations, detected by conventional staining and FISH with specific probes for chromosomes 8 and 11, compared with untreated controls $(p<0.05)$. Additionally, the frequencies of alterations at $11 q 23$, detected by $M L L$ specific probes, were significantly higher $(p<0.005)$ in treated cells than in controls. In contrast, an analysis of rearrangements involving the IGH gene did not disclose differences between treatments. The present results demonstrated the potential of etoposide to interact with preferential chromosome sites in human lymphocytes, even at concentrations below the mean plasma levels measured in cancer patients. This greater susceptibility to etoposide-induced cleavage may explain the more frequent involvement of $M L L$ in treatment-related leukemia.
\end{abstract}

Key words: etoposide, FISH, MLL translocations.

Received: July 2, 2008; Accepted: August 27, 2008.

\section{Introduction}

Etoposide is one of the most effective anticancer drugs frequently used for the treatment of hematological malignancies and solid tumors. However, its use has been associated with the development of secondary leukemia. The main target of this drug is the nuclear enzyme DNAtopoisomerase II that catalyzes topological changes necessary for normal DNA metabolism, including replication, transcription and recombination (Austin and Marsh, 1998). This drug, as well as other topoisomerase II inhibitors, exerts its toxic effects by inhibiting the enzyme function, thereby causing the accumulation of cleavable complexes and introducing high levels of transient protein-associated breaks in the genome of treated cells (Burden and Osheroff, 1998; Hande, 1998).

Send correspondence to María Sol Brassesco. Laboratório de Pediatria, Hospital das Clínicas, Faculdade de Medicina de Ribeirão Preto, Universidade de São Paulo, Av. Bandeirantes 3900, Bloco G, Bairro Monte Alegre, 14048-900 Ribeirão Preto, SP, Brazil. E-mail: marsol@ rge.fmrp.usp.br, solbrassesco@ hotmail.com.
Therapy related leukemias, associated with topoisomerase II inhibitors, often present rearrangements involving the $M L L$ gene on chromosome band $11 \mathrm{q} 23$, or to a lesser extent, $\mathrm{t}(8 ; 21), \mathrm{t}(3 ; 21) ; \mathrm{t}(8 ; 16), \mathrm{t}(15 ; 17), \mathrm{t}(9 ; 22)$ or inv(16), to then emerge as overt leukemias in a period of 2 to 3 years following therapy completion (Felix, 1998).

The $M L L$ gene plays an important role during fetal development and is a critical regulator of HOX genes during hematopoiesis. This function is subverted in leukemias through cleavage, recombination and chimeric fusion with more than 50 gene partners (Pais et al., 2005 Meyer et al., 2006). However, in contrast to the diversity with which $M L L$ translocates, the mapping of breakpoints revealed that most translocations occur within a $8.3 \mathrm{~kb}$ BamH1 fragment, known as the break-cluster region (BCR), located between exons 8 and 14 (Echlin-Bell et al., 2003). According to Strout et al., (1998), the BCR region presents 8 Alu repeats, various topoisomerase II consensus sites, 7/8 $X$-like octamers and V(D)J cryptic recognition signals, which might explain the high susceptibility of this gene to damaging agents. Nonetheless, other and subsequent studies have 
shown that DNA structure properties, such as scaffold associated regions and DNAse I hypersensitive sites, can act as recombination hot spots (Broeker et al., 1996; Strissel et al., 1998; Hensel et al., 2001; Reichel et al., 2001; Strick et al., 2006).

Furthermore, the biological evidence that leukemias in newborns originate in utero, has led to the hypothesis that maternal exposure to topoisomerase II inhibitors during pregnancy could be associated with an increased risk of leukemia (Ross, 2000). It is well known that synthetic and natural flavonoids interact with topoisomerase II and form the cleavable complex, in spite of being anticarcinogenic in certain cases (Greaves, 1997). According to Wiemels et al. (1999), the exposure of mothers and fetuses to substances that interact with the topoisomerase II inhibitors present in diets, medicines and the environment can in order of magnitude, be lower in terms of dose, when compared to the drugs used in chemotherapy. Nevertheless, in some cases they can be as biologically active as the topoisomerase II inhibitors used in cancer treatment.

Therefore, by considering the more frequent involvement of $M L L$ in treatment-related leukemogenesis, we aimed at studying whether low concentrations of etoposide would also preferentially promote 11q23 translocations over rearrangements within other chromosomal locations.

\section{Material and Methods}

\section{Blood culture and metaphase preparation}

Whole blood from three healthy donors (21 years old) were collected in a vacutainer containing the anticoagulant heparin, and cultured in a RPMI-1640 medium supplemented with $15 \%$ fetal bovine serum, $1 \%$ penicillinstreptomycin, 1\% l-glutamine (Gibco, Grand Island, NY), and $1 \%$ phytohemagglutinin-P (Gibco). Cell cultures were incubated at $37{ }^{\circ} \mathrm{C}$ in a $5 \% \mathrm{CO}_{2}$ moist atmosphere and harvested at $72 \mathrm{~h}$ after culture initiation. Twenty four hours after mitogenic stimulation, Etoposide (Nex-Vep, Bristol Myers Squibb) was added and cells were incubated for $48 \mathrm{~h}$ at $37{ }^{\circ} \mathrm{C}$ in final concentrations of $0.25,0.5$ and $1 \mu \mathrm{g} / \mathrm{mL}$. One set of cultures was treated for one hour-pulse, being subsequently washed twice in a RPMI 1640 medium, and subcultured in a supplemented medium until harvesting ( $47 \mathrm{~h}$ recovery period). Colcemid $(0.1 \mu \mathrm{g} / \mathrm{mL})$ was added $90 \mathrm{~min}$ prior to harvesting time. After hypotonic treatment $(0.075 \mathrm{M} \mathrm{KCl})$ for $30 \mathrm{~min}$ at $37^{\circ} \mathrm{C}$, cells were fixed three times with methanol: glacial acetic acid (3:1). The fixed cells were then dropped onto glass slides, allowed to air dry and stored at $-20^{\circ} \mathrm{C}$, until being used in the FISH technique.

\section{Fluorescence in situ hybridization}

FISH was performed using the commercially available probes LSI MLL Break Apart Rearrangement, according to manufacturer's protocol (Vysis, Downers Grove. IL). The Spectrum-Green labeled probe covers a $350 \mathrm{~kb}$ centromeric portion of the $M L L$ gene breakpoint region, while the Spectrum-Orange-labeled probe covers a $190 \mathrm{~kb}$ region telomeric to the BCR. In addition, LSI IGH Dual Color Break Apart Rearrangement probes (Vysis) were used. These probes hybridize with $14 \mathrm{q} 32$ and present the same characteristics as the probes for $11 \mathrm{q} 23$. In both cases, the pattern of expected signals for a normal nucleus is two green (yellow) orange signals. In cell harboring translocation, the green and orange signals appear separated without the yellow intersection. This strategy allows for the detection of translocations irrespective of the partner involved.

Chromosomal aberrations were also analyzed by using the whole chromosome painting Spectrum-Orange WCP-8 and Spectrum-Green WCP-11 probes (Vysis).Images were captured by using the Axiovision System (Zeiss, Germany).

\section{Detection of apoptotic cells}

Apoptotic cells were recognized by nuclear condensation and fragmentation. Treated cells were centrifuged and incubated for $5 \mathrm{~min}$ at $37{ }^{\circ} \mathrm{C}$ with bisbenzimide (Hoechst 33342), propidium iodide and fluorescein diacetate (Sigma Chemical Co., St. Louis, U S A). Then, samples were mounted, coverslipped and analyzed by fluorescence microscopy with a triple filter. Cells were scored and categorized according to differential staining: (1) normal: blue nucleus and green cytoplasm, (2) apoptotic: fragmented blue nucleus and green cytoplasm and (3) necrotic: spherical red nucleus. Five hundred nuclei were analyzed per treatment.

\section{Statistical analysis}

Statistical analyses were performed by using SigmaStat (Jandel Scientific, Co) software. All tests were carried out for $\alpha=0.05$.

\section{Results}

The clastogenic effects of etoposide on different genomic regions were analyzed in lymphocyte cultures from 3 healthy probands. Cultures were treated with three drug concentrations, $0.25,0.5$ and $1 \mu \mathrm{g} / \mathrm{mL}$. Etoposidetreated cells presented a reduction in mitotic indexes (calculated for 1000 cells), albeit there were no significant differences among treatments $(\mathrm{p}>0.05)$. Etoposide induced a statistically significant increase in frequencies of chromosome aberration relative to negative controls $(\mathrm{p}<0.0005$, One Way Repeated Measures ANOVA). On comparing the different treatments and controls, the Bonferroni method showed significant differences for continuous exposure to etoposide $(\mathrm{p}<0.05)$ (Table 1$)$. Cytogenetic analysis by FISH with whole chromosome probes indicated increased frequencies of altered cells and aberrations located at chromosome 11, when treated cultures and controls were com- 
Table 1 - Mitotic indexes, chromosome aberration distribution (CAs), total CAs and altered metaphases in cultures treated with etoposide. Independent experiments were performed with blood samples from three individuals.

\begin{tabular}{|c|c|c|c|}
\hline Treatment & Mitotic index (mean $\pm \mathrm{SD})$ & Total $\mathrm{CAs}^{\#} / 100$ cells $($ mean $\pm \mathrm{SD})$ & Altered Metaphases $/ 100$ cells $($ mean $\pm \mathrm{SD}$ ) \\
\hline Control & $5.14 \pm 2.30$ & $1.58 \pm 0.57$ & $1.58 \pm 0.57$ \\
\hline $0.25 \mu \mathrm{g} / \mathrm{mL}(1 \mathrm{~h})$ & $5.79 \pm 2.28$ & $7.3 \pm 0.57$ & $6.31 \pm 0.57$ \\
\hline $0.5 \mu \mathrm{g} / \mathrm{mL}(1 \mathrm{~h})$ & $5.12 \pm 1.04$ & $8.14 \pm 2.08$ & $6.83 \pm 1.73$ \\
\hline $1 \mu \mathrm{g} / \mathrm{mL}(1 \mathrm{~h})$ & $4.78 \pm 2.34$ & $9.22 \pm 3.78$ & $7.36 \pm 2.51$ \\
\hline $0.25 \mu \mathrm{g} / \mathrm{mL}(48 \mathrm{~h})$ & $2.71 \pm 1.04$ & $81.97 \pm 13.20^{*}$ & $35.72 \pm 11.53 *$ \\
\hline $0.5 \mu \mathrm{g} / \mathrm{mL}(48 \mathrm{~h})$ & $2.92 \pm 1.36$ & $93.77 \pm 58.73 *$ & $45.88 \pm 22.94 *$ \\
\hline $1 \mu \mathrm{g} / \mathrm{mL}(48 \mathrm{~h})$ & $1.89 \pm 0.17$ & $168.76 \pm 44.19^{*}$ & $74.01 \pm 12.42 *$ \\
\hline
\end{tabular}

"Chromosome aberrations included chromatidic and chromosome gaps. chromatid and chromosome breaks; fragments. double minutes and other aberrations such as rings. dicentrics. triradial. tetraradial. and complex aberrations.

*Statistically different. $\mathrm{p}<0.05$.

Modality of treatment is indicated in brackets: $1 \mathrm{~h}$ pulse and $48 \mathrm{~h}$ continuous treatment.

pared $(\mathrm{p}<0.05$, Friedman Repeated Measures ANOVA on Ranks), in both cases (Table 2). Mean numbers of 800 metaphases were analyzed. Alterations in chromosome 8 also showed increased frequencies $(\mathrm{p}<0.05)$. For both chromosomes, the comparison of different treatments against controls performed by the Bonferroni method showed significant differences for continuous exposure to etoposide $(\mathrm{p}<0.05)$. The individual comparison of mean aberration frequencies per treatment calculated for chromosomes 8 and 11 showed statistically higher frequencies for chromosome 11 than for chromosome 8 , in some drug concentrations (Figure 1).

The specific induction of translocations at 11q23 was also analyzed by using the $M L L$ gene probe (Vysis). $M L L$ rearrangements were scored in nuclei presenting a hybridization pattern with clearly distinct separation of signals. Statistical analysis showed significant differences $(\mathrm{p}<0.0005$, One Way ANOVA) between treated and untreated cultures. In contrast, the analysis of rearrangements involving the $I G H$ gene (14q32) did not disclose significant differences between treatments ( $p>0.05$, One-Way Repeated Measures ANOVA) (Figure 2). Extra signals were

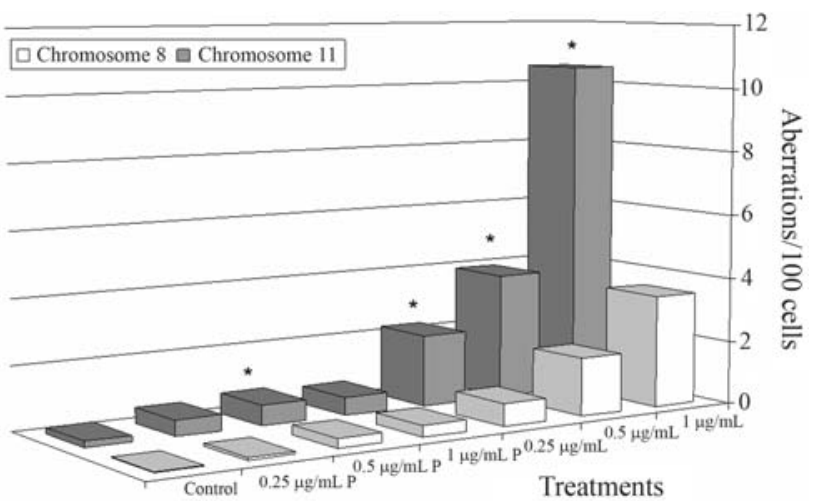

Figure 1 - Mean aberration frequencies on chromosomes 8 and 11 (detected by chromosome painting), observed in lymphocyte cultures treated with different etoposide concentrations and negative controls. P: onehour-pulse treatment. ${ }^{*}$ Statistically different $\mathrm{p}<0.05$. also detected by both specific probes, but their frequencies were not significantly increased $(p>0.05)$ in treated cultures. Hybridization patterns and examples of chromosome aberrations are presented in Figure 3.

It has been suggested that $M L L$ aberrations could result from chromatin fragmentation at initial stages of

Table 2 - Altered metaphases and chromosomal aberrations (CAs) detected with specific probes for chromosomes 8 and 11 in peripheral blood lymphocytes treated with etoposide. 1000 cells were analyzed per treatment/experiment.

\begin{tabular}{lcc}
\hline Treatment & $\begin{array}{c}\text { Altered Metaphases } / 100 \\
\text { cells }(\text { mean } \pm \text { SD })\end{array}$ & $\begin{array}{c}\text { Total CAs }{ }^{\#} / 100 \text { cells } \\
(\text { mean } \pm \text { SD) }\end{array}$ \\
\hline & Chromosome 11 & \\
Control & $2.00 \pm 2.00$ & $0.186 \pm 0.19$ \\
$0.25 \mu \mathrm{g} / \mathrm{mL}(1 \mathrm{~h})$ & $3.03 \pm 2.88$ & $0.46 \pm 0.18$ \\
$0.5 \mu \mathrm{g} / \mathrm{mL}(1 \mathrm{~h})$ & $3.10 \pm 7.81$ & $0.34 \pm 0.82$ \\
$1 \mu \mathrm{g} / \mathrm{mL}(1 \mathrm{~h})$ & $4.04 \pm 4.93$ & $0.46 \pm 0.46$ \\
$0.25 \mu \mathrm{g} / \mathrm{mL}(48 \mathrm{~h})$ & $21.10 \pm 9.45^{*}$ & $2.11 \pm 0.94^{*}$ \\
$0.5 \mu \mathrm{g} / \mathrm{mL}(48 \mathrm{~h})$ & $17.01 \pm 9.60^{*}$ & $3.89 \pm 0.67^{*}$ \\
$1 \mu \mathrm{g} / \mathrm{mL}(48 \mathrm{~h})$ & $48.70 \pm 19.13^{*}$ & $9.85 \pm 4.21^{*}$ \\
\hline & Chromosome 8 & \\
$\mathrm{Control}$ & $0.33 \pm 0.57$ & $0.03 \pm 0.00$ \\
$0.25 \mu \mathrm{g} / \mathrm{mL}(1 \mathrm{~h})$ & $0.66 \pm 0.57$ & $0.08 \pm 0.00$ \\
$0.5 \mu \mathrm{g} / \mathrm{mL}(1 \mathrm{~h})$ & $2.15 \pm 2.08$ & $0.22 \pm 0.24$ \\
$1 \mu \mathrm{g} / \mathrm{mL}(1 \mathrm{~h})$ & $3.33 \pm 2.88$ & $0.22 \pm 0.30$ \\
$0.25 \mu \mathrm{g} / \mathrm{mL}(48 \mathrm{~h})$ & $6.46 \pm 2.08^{*}$ & $0.70 \pm 0.16^{*}$ \\
$0.5 \mu \mathrm{g} / \mathrm{mL}(48 \mathrm{~h})$ & $15.28 \pm 1.52^{*}$ & $1.76 \pm 0.55^{*}$ \\
$1 \mu \mathrm{g} / \mathrm{mL}(48 \mathrm{~h})$ & $12.29 \pm 13.45^{*}$ & $3.28 \pm 1.43^{*}$ \\
\hline
\end{tabular}

${ }^{\#}$ Chromosome aberrations included chromatidic and chromosome gaps. chromatid and chromosome breaks; fragments. double minutes and other aberrations such as rings. dicentrics. triradial. tetraradial. and complex aberrations.

*Statistically different. $\mathrm{p}<0.05$.

Modality of treatment is indicated in brackets: $1 \mathrm{~h}$ pulse and $48 \mathrm{~h}$ continuous treatment. 

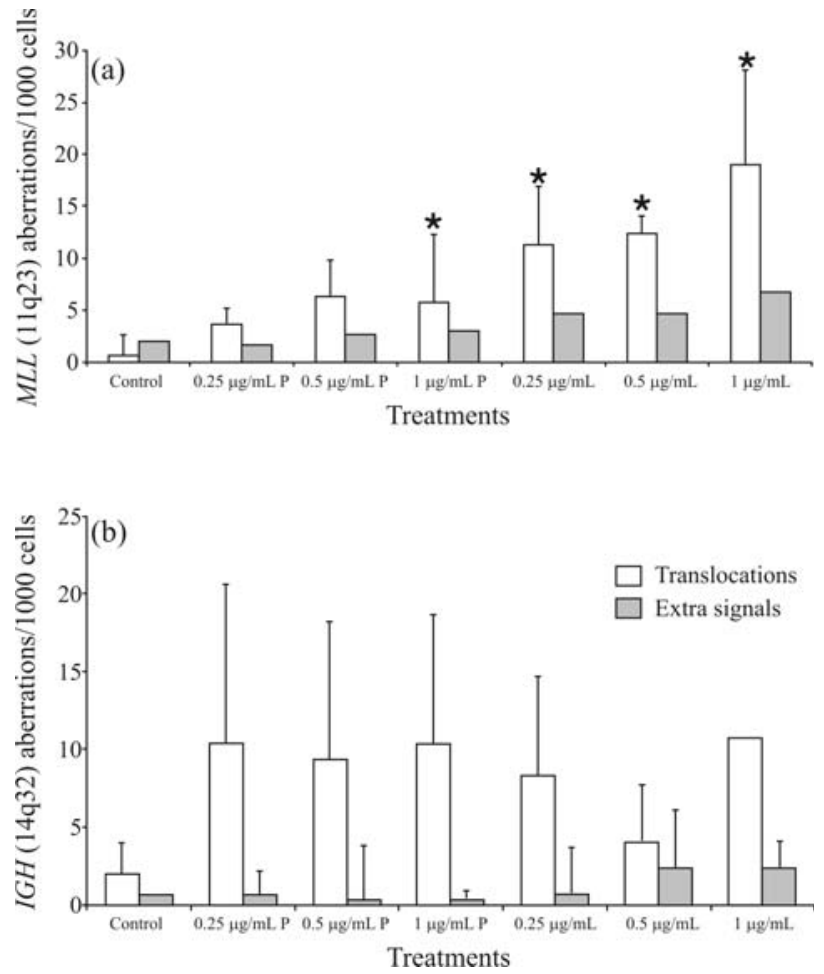

Figure 2 - $M L L(\mathrm{~A})$ and $I G H(\mathrm{~B})$ mean translocation and extra signal frequencies observed in peripheral blood lymphocytes cultures treated with different etoposide concentrations. P: one-hour-pulse treatment. *statistically different. $\mathrm{p}<0.05$.
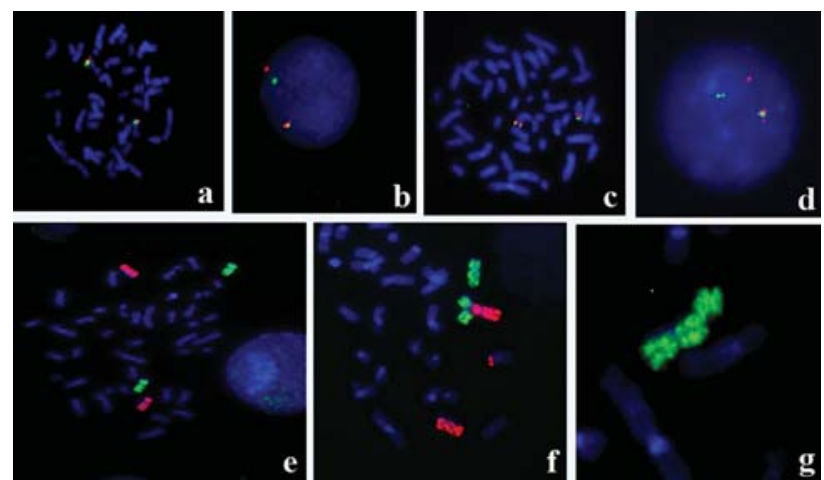

Figure 3 - FISH analysis of peripheral lymphocytes treated with etoposide. a) and b) Normal methaphase with two $M L L$ copies at 11q23 and translocated nucleus presenting the separation of signals, respectively. c) Normal metaphase with two $I G H$ gene copies at 14q32. d) Translocated nucleus presenting the separation of signals. e) Normal metaphase showing chromosome pair 8 (WCP 8 Spectrum-Green) and chromosome pair 11 (WCP 11 Spectrum-orange). f) Partial metaphase showing a triradial chromosome involving both chromosomes. g) Partial metaphase showing a chromatid break. Figures of altered cells correspond to $1 \mu \mathrm{L} / \mathrm{mL}$ etoposide treatment.

apoptosis. However, treated lymphocytes did not show etoposide-induced apoptosis $(\mathrm{p}>0.05)$. Similarly, frequencies of necrotic cells did not significantly differ $(p>0.05)$ from controls (Figure 4).
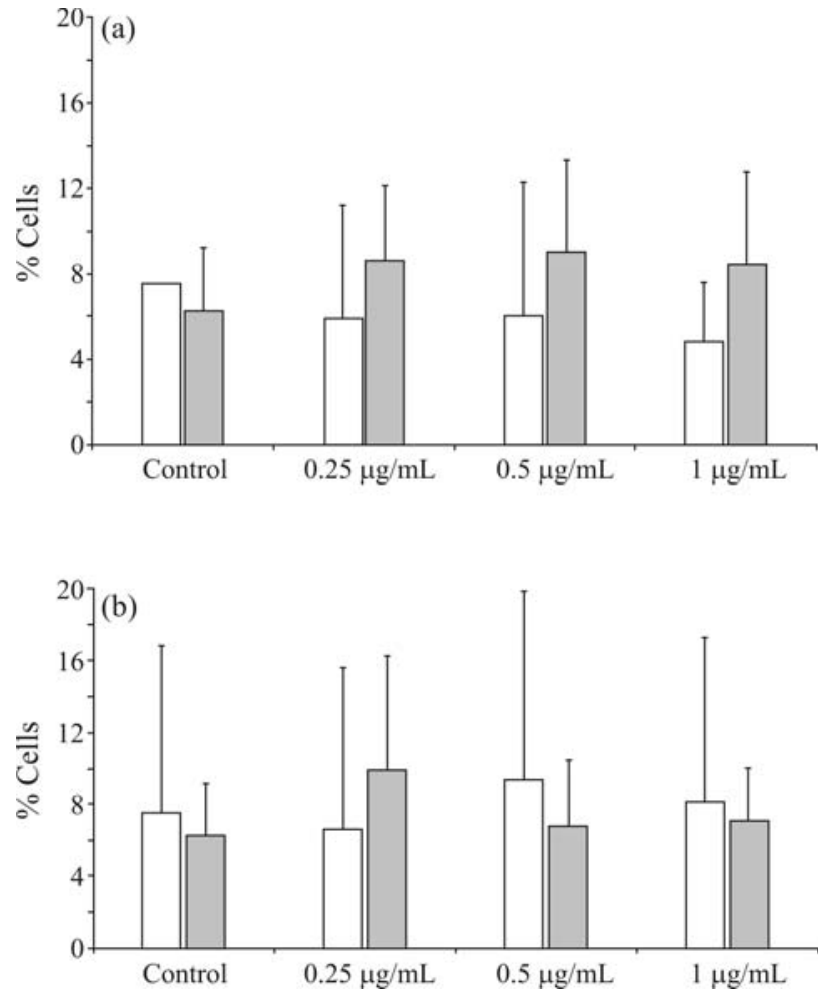

Figure 4 - Mean aberration frequencies of apoptotic (white bars) and necrotic (grey bars) cells observed in negative controls and in lymphocyte cultures treated with different etoposide concentrations: A) One-hourpulse treatment and B) continous $48 \mathrm{~h}$ treatment.

\section{Discussion}

In the present study, we observed a statistically significant increase in the frequencies of chromosome aberration in peripheral lymphocyte cultures treated with low etoposide concentrations. On comparing with controls, this increase proved to be higher in the continuous $48 \mathrm{~h}$ treatment. Treated cultures also showed a reduction in mitotic indexes, even though the differences between treatments were not significant. Several studies have demonstrated that cells are more sensitive to etoposide when treated during the S-phase of the cell cycle, although formation of the cleavable complex has been reported to occur at all phases (Berger et al., 1991). It has been suggested that at low concentrations, the cleavable complex could initiate a series of events that would culminate in the elimination of cells through necrosis or apoptosis (Froelich-Ammon and Osheroff, 1995). In the present study, the morphological analysis of cells by differential fluorescent staining did not show significant induction of apoptotic and necrotic cells by different etoposide concentrations.

A direct correspondence between topoisomerase II consensus sequences and the breakpoints described in therapy-related leukemias has been reported (Felix, 1998). Furthermore, rearrangements at 11q23 are highly reproducible in culture under conditions of treatment with topoiso- 
merase II inhibitors (Aplan et al., 1996). There is also evidence that etoposide-metabolites, cathecol and quinone, also induce breaks at $M L L \mathrm{BCR}$, as observed for the drug itself (Lovett et al., 2001). The present results demonstrate the clastogenic activity of etoposide, even at low concentrations over short periods, placed in evidence by the induction of aberrations at chromosome 11 and $M L L$ gene, as detected by FISH with specific probes. Aplan et al. (1996) showed that double-strand breaks can be induced in vitro in myeloid lineages with concentrations as low as $3 \mu \mathrm{mol}$ $(1.7 \mu \mathrm{g} / \mathrm{mL})$, and that such breaks increase with higher doses, with a plateau at concentrations between 30-100 $\mu \mathrm{mol}(17-58 \mu \mathrm{g} / \mathrm{mL})$. These authors also demonstrated that site-specific cleavage did not require continuous treatments, since cells treated for one hour and recovered after $24 \mathrm{~h}$ presented specific cleavage at 11q23.

Our results showed differences between treated and untreated cells even at the lowest concentration (etoposide $0.25 \mu \mathrm{g} / \mathrm{mL}), \sim 0.4 \mu \mathrm{mol}$, for one-hour pulse. However, the clastogenic effect was more pronounced under conditions of continuous treatments for $48 \mathrm{~h}$, which is the maximum period of drug stability in cultures (Mader et al., 1991). Even though Aplan et al. (1996) showed that the induction of aberrations did not require continuous drug exposure, other authors demonstrated that the effects of topoisomerase II inhibitors disappear after drug removal (Binaschi et al., 1990), suggesting that at low concentrations the possibilities of DNA repair seem to be higher.

Regarding aberrations at the $M L L$ gene, Moneypenny et al. (2006) demonstrated the induction of breaks (assessed by the comet assay) in fetal hematopoietic cells exposed to low concentrations of etoposide $(0.3 \mu \mathrm{g} / \mathrm{mL})$. Furthermore, increased frequencies of $M L L$ rearrangements were also detected by FISH after $24 \mathrm{~h}, 72 \mathrm{~h}$ and 7 days following treatment with etoposide 0.3 and $0.6 \mu \mathrm{g} / \mathrm{mL}$.

The recurrent association of $11 \mathrm{q} 23$ translocations with therapy-related leukemias has led to the suggestion that this region might be preferentially damaged by topoisomerase II inhibitors, and consequently, chromosome 11 might present more aberrations compared with other chromosomes. With this in view, we proposed to analyze induced-damage at chromosome 8 (involved to a lesser extent as it is in leukemia-associated translocations) and at the $I G H$ gene (14q32), also involved in lymphoid malignancies.

The analysis of chromosome 8 showed a significant increase of chromosomal aberrations in treated cultures relative to controls, in continuous treatment with etoposide ( 0.5 and $1 \mu \mathrm{g} / \mathrm{mL}$ ), but a comparison of mean aberration frequencies calculated for chromosomes 8 and 11 showed significantly higher frequencies for 11 compared to 8 . In addition, rearrangements involving the $I G H$ gene (14q32) did not significantly $(\mathrm{p}>0.05)$ increase after etoposide treatment, indicating that this gene is not affected to the same extent as the $M L L$ gene by induced-chromosome breaks under the same conditions.

Similarly, the non-random induction of aberrations by etoposide was previously reported by Maraschin et al. (1990), demonstrating that chromosomes 1, 11 and 17 were more involved in aberrations than chromosomes 4, 5 and X, which were rarely affected. Regarding other chromosomes, Mosesso et al., (1998) showed that the frequencies of aberrations at chromosomes 2, 4 and 8 were 20\%-30\% higher than those observed for chromosomes 1, 3 and X.

Differences in susceptibility to induced-breaks might be related to certain characteristics of chromosome structure, since R-band rich chromosomes, such as chromosome 11, are more sensitive than G-band rich ones (Maraschin et al., 1990). In CD $34^{+}$cells treated with etoposide, Libura et al. (2005) showed that aberrations at chromosome 11 occur at frequencies twice as high as at chromosome 4, suggesting that even though $\mathrm{t}(4 ; 11)$ is the most frequent translocation in some leukemias, there is still a difference concerning susceptibility to etoposide induced-damage. Also, Escobar et al. (2007) showed by comet-FISH assays that etoposide produced more DNA damage at 11q23 in relation to the long arm of chromosomes 5, more specifically $5 q 31$, which is often deleted secondary leukemias associated by previous treatment with alkylating agents.

Previous studies on drug clastogenicity performed at the gene level were unable to detect specific damage at several loci, including SCL, ENL, AF6, TCR $\beta, T C R \gamma$ and $T C R \delta$, in etoposide-treated cells (Aplan et al., 1996). Likewise, $\mathrm{Ng}$ et al. (2006) reported a higher susceptibility of the $M L L$ gene to treatments with etoposide 10-100 $\mu \mathrm{mol}$ compared to the leukemia-associated $R U N X 1$ and $A F 9$ genes.

It has been reported that the origin of gene fusions in lymphoid malignancies, such as $\mathrm{t}(14 ; 18)$ IGH/BCL2, $\mathrm{t}(11 ; 14) \quad I G H / C C D 1, \mathrm{t}(11 ; 14) \quad$ LMO2/TCR and $\mathrm{t}(7 ; 9)$ $T C R / T A L 2$, among others, might involve the $\mathrm{V}(\mathrm{D}) \mathrm{J}$ recombination process (responsible for the rearrangements at T-cell receptor and immunoglobulin genes), apparently through the recognition of heptamer-nonamer cryptic sequences (Vega and Medeiros, 2003).

Increased illegitimate recombination frequencies at $T C R$ genes have been identified in agricultural workers exposed to pesticides (Lipkowitz et al., 1992) and in patients under chemotherapy (Abdallah et al., 1995). Chen et al. (1996) demonstrated that etoposide induces site-specific rearrangements consistent with $\mathrm{V}(\mathrm{D}) \mathrm{J}$-recombinase, by studying deletions at the HPRT gene level. The loss of exons 2 and 3 appeared to have increased in non-lymphoid cells in a concentration-dependent manner under continuous etoposide-treatment.

In our study, the analysis of the $I G H$ gene (14q32) demonstrated only a slight increase in the frequency of aberrations, through different treatments for one hour-pulse. Illegitimate $\mathrm{V}(\mathrm{D}) \mathrm{J}$ recombination has also been associated with the origin of $M L L$ aberrations, probably due to the 
presence of consensus signal sequences at BCR. Gu et al. (1992) reported cryptic heptamer-nonamer sequences when analyzing breakpoints at $M L L$ and $A F 4$, involved in $\mathrm{t}(4 ; 11)$, suggesting that the $\mathrm{V}(\mathrm{D}) \mathrm{J}$-recombinase complex could be directly associated with the emergence of translocation. The involvement of this process has also been suggested by Whitmann et al., (2001), who detected illegitimate recognition sequences at the breakpoint junctions between $M L L$ intron 6 and $A F 9$ intron 8 in patients with leukemia harboring $\mathrm{t}(9 ; 11)$. In parallel, several studies have demonstrated the induction of $M L L$ aberrations after exposure of cells to different apoptotic stimuli (Stanulla et al., 1997; Sim \& Liu , 2002; Betti et al., 2003).

However, there is increasing evidence showing that certain properties related to DNA structure, such as scaffold associated regions and DNAse I hypersensitive sites, indeed act as recombination hot spots (Broeker et al., 1996; Strissel et al., 1998; Hensel et al., 2001; Reichel et al., 2001; Strick et al., 2006). Interestingly, Scharf et al., (2007) demonstrated that the etoposide cleavage site at the $M L L$ gene resides within a RNA polymerase II binding site.

In childhood leukemia patients, the mean plasma concentration of topoisomerase II inhibitors is $1.7 \mu \mathrm{mol}$ $(1 \mu \mathrm{g} / \mathrm{mL})$ in chronic treatments (Edick et al., 2003), reaching $25 \mu \mathrm{mol}$ after $6 \mathrm{~h}$ from administration in some treatment schedules. Some controversy exists in the literature regarding dosage and duration of treatment in the development of therapy-related leukemias. According to Megonigal et al. (2000), there is a dose-response relationship in patients treated with alkylating agents but this would not be the case for patients treated with epipodophyllotoxins. On the contrary, other authors postulate the existence of a direct leukemogenic effect after etoposide treatment, dependent on the time and dose administered (Dann and Rowe, 2001). There are reports of t-AML development after exposure to few doses of topoisomerase II inhibitors (Blanco et al., 2001).

Although the factors influencing the predisposition of the $M L L$ gene to induced damage by topoisomerase II inhibitors are still unknown, the presence of topoisomerase II consensus sites, scaffold-associated regions and other sequences (such as Alu repeats, cryptic V(D)J signal and 7/8 $X$-like sequences, among others), suggest that this gene might be more vulnerable to breakage by enzymes, toxic chemicals and metabolites.

Thus, the increase of $M L L$ aberrations induced after treatment with low doses of etoposide, as shown in the present study, provides relevant information regarding the potential effects of etoposide in in vivo exposure, demonstrating the evident predisposition of this gene to drug-induced chromosome damage, even at concentrations below the limits observed for patients under chemotherapy.

\section{Acknowledgments}

We are grateful to donors whose cooperative spirit was remarkable. We also thank Sueli A. Neves and Luiz A. da Costa Jr. for technical assistance. This work was supported by FAPESP (Proc. 02/13317-8 and 03/01915-0), CAPES and CNPq.

\section{References}

Abdallah JM, Lombardi DP and Kirsch IR (1995) Genetic instability in patients with Hodgkin's disease undergoing chemotherapy. J Clin Invest 96:2744-2747.

Aplan PD, Chervinsky DS, Stanulla M and Burhans WC (1996) Site-specific DNA cleavage within the MLL breakpoint cluster region induced by Topoisomerase II inhibitors. Blood 87:2649-2658.

Austin CA and Marsh KL (1998) Eukaryotic DNA Topoisomerase II $\beta$. Bioassays 20:215-226.

Berger A, Chatterjee JA, Schmotzer C and Helms SR (1991) Etoposide (VP-16-213)-induced gene alterations: Potential contribution to cell death. Proc Natl Acad Sci USA 88:8740-8743.

Betti CJ, Villalobos MJ, Diaz MO and Vaughan TM (2003) Apoptotic stimuli initiate MLL-AF9 translocations that are transcribed in cells capable of division. Cancer Res 63:1377-1381.

Binaschi M, Capranico G, De Isabella P, Mariani M, Supino R, Tinelli S and Zunino F (1990) Comparison of DNA cleavage induced by etoposide and doxorubicin in two human smallcell lung cancer lines with different sensitivities to topoisomerase II inhibitors. Int J Cancer 45:347-352.

Blanco JG, Dervieux T, Edick MJ, Mehta PK, Rubnitz JE, Shurtleff S, Raimondi SC, Behm FG, Pui C and Relling M (2001) Molecular emergence of acute myeloid leukemia during treatment for acute lymphoblastic leukemia. Proc Natl Acad Sci USA 98:10338-10343.

Broeker PL, Super HG, Thirman MJ, Pomykala H, Yonebayashi Y, Tanabe S, Zeleznik-Le N and Rowley JD (1996) Distribution of 11q23 breakpoints within the MLL breakpoint cluster region in de novo acute leukemia and in treatmentrelated acute myeloid leukemia: Correlation with scaffold attachment regions and topoisomerase II consensus binding sites. Blood 87:1912-1922.

Burden DA and Osheroff N (1998) Mechanism of action of eukaryotic topoisomerase II and drugs targeted to the enzyme. Biochim Biophys Acta 1400:139-154.

Chen CL, Fuscoe JC, Liu Q and Relling MV (1996) Etoposide causes illegitimate $\mathrm{V}(\mathrm{D}) \mathrm{J}$ recombination in human lymphoid leukemic cells. Blood 88:2210-2218.

Dann EJ and Rowe JM (2001) Biology and therapy of secondary leukaemias. Best Pract Res Clin Haematol 14:119-137.

Echlin-Bell DR, Smith LL, Li L, Strissel PL, Strick R, Gupta V, Banerjee J, Larson R, Relling MV, Raimondi SC et al. (2003) Polymorphisms in the MLL breakpoint cluster region (BCR). Hum Genet 113:80-91.

Edick MJ, Gajjar A, Mahmoud HH, Van De Poll ME, Harrison PL, Panetta JC, Rivera GK, Ribeiro RC, Sandlund JT, Boyett JM et al. (2003) Pharmacokinetics and pharmacodynamics of oral Etoposide in children with relapsed or refractory acute lymphoblastic leukemia. J Clin Oncol 21:1340-1346. 
Escobar PA, Smith MT, Vasishta A, Hubbard AE and Zhang L. (2007) Leukaemia-specific chromosome damage detected by comet with fluorescence in situ hybridization (cometFISH). Mutagenesis 22:321-327.

Felix CA (1998) Secondary leukemias induced by Topoisomerase-targeted drugs. Biochim Biophys Acta 1400:233-255.

Froelich-Ammon SJ and Osheroff N (1995) Topoisomerase poisons: Harnessing the dark side of enzyme mechanism. J Biol Chem 270:21429-21432.

Greaves M (1997) Aetiology of acute leukaemia. Lancet 349:344-349.

Gu Y, Cimino G, Alder H, Nakamura T, Prasad R, Canaani O, Moir DT, Jones C, Nowell PC, Croce CM, et al. (1992) The $(4 ; 11)(\mathrm{q} 21 ; \mathrm{q} 23)$ chromosome translocations in acute leukemias involve the VDJ recombinase. Proc Natl Acad Sci USA 89:10464-10468.

Hande KR (1998) Etoposide: Four decades of development of a topoisomerase II inhibitor. Eur J Cancer 34:1514-1521.

Hensel JP, Gillert E, Fey GH and Marschalek R (2001) Breakpoints of $\mathrm{t}(4 ; 11)$ translocations in the human MLL and AF4 genes in ALL patients are preferentially clustered outside high-affinity matrix attachment regions. J Cell Biochem 82:299-309.

Libura J, Slater DJ, Felix CA and Richardson C (2005) Therapy-related acute myeloid leukemia-like MLL rearrangements are induced by Etoposide in primary human CD34+ cells and remain stable after clonal expansion. Blood 105:2124-2131.

Lipkowitz S, Garry VF and Kirsh IR (1992) Interlocus V-J recombination measures genomic instability in agriculture workers at risk for lymphoid malignancies. Proc Natl Acad Sci USA 89:5301-5305.

Lovett BD, Strumberg D, Blair IA, Pang S, Burden DA, Megonigal MD, Rappaport EF, Rebbeck TR, Osheroff N, Pommier YG et al. (2001) Etoposide metabolites enhance DNA Topoisomerase II cleavage near leukemia-associated MLL translocation breakpoints. Biochemistry 40:1159-1170.

Mader RM, Steger GG, Moser K, Rainer H, Krenmayr P and Dittrich C (1991) Instability of the anticancer agent Etoposide under in vitro culture conditions. Cancer Chemother Pharmacol 27:354-360.

Maraschin J, Dutrillaux B and Aurias A (1990) Chromosome aberrations induced by Etoposide (VP-16) are not random. Int J Cancer 46:808-812.

Megonigal MD, Cheung NV, Rappaport EF, Nowell PC, Wilson RB, Jones DH, Addya K, Leonard DGB, Williams TM, Lange BJ et al. (2000) Detection of leukemia-associated MLL-GASP translocation early during chemotherapy with DNA Topoisomerase II inhibitors. Proc Natl Acad Sci USA 97:2814-2819.

Meyer C, Kowarz E, Schneider B, Oehm C, Klingebiel T, Dingermann T and Marschalek R (2006) Genomic DNA of leukemic patients: Target for clinical diagnosis of MLL rearrangements. Biotechnol J 1:656-663.

Moneypenny CG, Shao J, Song Y and Gallagher EP (2006) MLL rearrangements are induced by low doses of Etoposide in human fetal hematopoietic stem cells. Carcinogenesis 27:874-881.

Mosesso P, Darroudi F, Van Den Berg M, Vermeulen S, Palitti F and Natarajan AT (1998) Induction of chromosomal aberrations (unstable and stable) by inhibitors of Topoisomerase II, m-AMSA and VP16, using conventional Giemsa staining and chromosome painting techniques. Mutagenesis 13:3943.

$\mathrm{Ng}$ A, Taylor GM and Eden OB (2006) Genotoxicity of Etoposide: Greater susceptibility of MLL than other target genes. Cancer Genet Cytogenet 164:164-167.

Pais A, Kadam P, Raje G, Sawant M, Kabre S, Jain H, Advani S and Banavali S (2005) Identification of various MLL gene aberrations that lead to MLL gene mutation in patients with acute lymphoblastic leukemia (ALL) and infants with acute leukemia. Leuk Res 29:517-526.

Reichel M, Gillert E, Angermüller S, Hensel JP, Heidel F, Lode M, Leis T, Biondi A, Haas OA, Strehl S et al. (2001) Biased distribution of chromosomal breakpoints involving the MLL gene in infants versus children and adults with $\mathrm{t}(4 ; 11)$ ALL. Oncogene 20:2900-2907.

Ross JA (2000) Dietary flavonoids and the MLL gene: A pathway to infant leukemia? Proc Natl Acad Sci USA 97:4411-4413.

Scharf S, Zech J, Bursen A, Schraets D, Oliver PL, Kliem S, Pfitzner E, Gillert E, Dingermann T and Marschalek R (2007) Transcription linked to recombination: A geneinternal promoter coincides with the recombination hot spot II of the human MLL gene. Oncogene 26:1361-1371.

Sim S and Liu L (2002) Nucleolytic cleavage of the mixed lineage leukemia breakpoint cluster region during apoptosis. J Biol Chem 276:31590-31595.

Stanulla M, Wang J, Chervinsky DS, Thandla S and Aplan PD (1997) DNA cleavage within the MLL break cluster region is a specific event which occurs as part of higher-order chromoatin fragmentation during the initial stages of apoptosis. Mol Cell Biol 17:4070-4079.

Strick R, Zhang Y, Emmanuel N and Strissel PL (2006) Common chromatin structures at breakpoint cluster regions may lead to chromosomal translocations found in chronic and acute leukemias. Hum Genet 119:479-495.

Strissel PL, Strick R, Rowley JD and Zeleznik-Le NJ (1998) An in vivo topoisomerase II cleavage site and a DNase I hypersensitive site colocalize near exon 9 in the MLL breakpoint cluster region. Blood 92:3793-3803.

Strout MP, Marcucci G, Bloomfield CD and Caligiuri MA (1998) The partial tandem duplication of ALL1 (MLL) is consistentently generated by Alu-mediated homologous recombination in acute myeloid leukemia. Proc Natl Acad Sci USA 95:2390-2395.

Vega F and Medeiros LJ (2003) Chromosomal translocations involved in non-Hodgkin lymphomas. Arch Pathol Lab Med 127:1148-1160.

Wiemels JL, Pagnamenta A, Taylor MG, Eden OB, Alexander FE, Greaves MF and United Kingdom Childhood Cancer Study Investigators (1999) A lack of a functional NAD(P)H: quinone oxidoreductase allele is selectively associated with pediatric leukemias that have MLL fusions. Cancer Res 59:4095-4099.

Whitman SP, Strout MP, Marcucci G, Freud AG, Culley LL, Zeleznik-Le NJ, Mrózek K, Theil KS, Kees UR, Bloomfield CD et al. (2001) The partial nontandem duplication of the MLL (ALL1) gene is a novel rearrangement that generates three distinct fusion transcripts in B-cell acute lymphoblastic leukemia. Cancer Res 61:59-63.

Associate Editor: Carlos F.M. Menck

License information: This is an open-access article distributed under the terms of the Creative Commons Attribution License, which permits unrestricted use, distribution, and reproduction in any medium, provided the original work is properly cited. 